\title{
Environmental standards and judgment processes in competitions for public buildings
}

\section{Jean-Pierre Chupin, Carmela Cucuzzella, Montréal}

\section{Introduction}

This article highlights the often underestimated impact of environmental standards on the judgment process with particular reference to contemporary Canadian competitions for public buildings. It argues that recent attention given to environmental standards could lead to a potential crisis in the competition process. After establishing a clear distinction between evaluation and judgment, the article offers to reassess current practices through a theoretical model, which shifts from «judgment on design» to «judgment by design».

Contrary to calls for public tender or public-private partnerships, the public building competition distinguishes itself through a comparison of proposals in the form of «projects». Besides the evaluation of technical, quantitative or budgetary aspects, these projects are judged on the basis of their intrinsic qualities. Despite the importance of the competition process for the quality of public buildings (ADAMCZYK 2004; STRONG 1996), this procedure is not exempt from its problems, in particular in what concerns the judgment criteria and the qualitative evaluation of the projects. Indeed, the judgment process is complex by nature in architectural, landscape and urban planning competitions but has nevertheless been far too little theorized.

In this theoretical «vacuum», two trends that may currently be observed have the potential to complicate the judgment process further. The growing demand for the diversification of jury members, where the heterogeneity of the jury is considered synonymous with the diversification of viewpoints, and the marked increase in the use of standard environmental methods (i.e. Leadership in Energy and Environmental Design - LEED). These two trends are closely related, since it is not the plurality of views that is problematic in a judgment process, as discordance is seen as a necessary dimension for reflection and judgment, but the coercive nature of the diverse worldviews that the heterogeneity of jurors may represent. For example, the inclusion of a LEED expert on the jury not only changes its constitution, but may considerably affect the outcome because of the relationship that jurors have to the results of this evaluation method.

Because of the increasing demand worldwide for the use of standardised methods for assessing sustain- ability (Moore \& ENGSTrom 2005), not only has the development of such methods over the past 30 years grown dramatically, but their importance for the planning and creation of public buildings has in turn been impacted - and not always in the way that is most obvious. This phenomenon may be seen in Canada, and is likely to be similar elsewhere.

In this paper, the focus is on specific weaknesses in the judgment process regarding the adoption of the environmental standard LEED. The discussion is illustrated by examples taken from the Canadian context. It concludes with a call to reconsider judgment in architecture, which instead of being an operation of evaluation or even a form of criticism from outside the project, would rather be considered from inside the project. In other words, what is often understood as «judgment on the design» would in fact consist of a form of «judgment by design», meaning that the collective act of judging indeed participates to the elaboration of the project itself, as most constructive judgments would. This is not intended to be prescriptive but precisely descriptive as a more accurate theoretical model of a vast majority of practices. This paradigm shift would offer not only a way to theorize judgment in the domain of architecture, landscape and urbanism, but also a way to better contextualize environmental standards.

\section{Standard environmental evaluation methods and the competition process in Canada}

Like most professional organisations, the Royal Architectural Institute of Canada (www.raic.org) defines an architectural competition as a method of

«obtaining a design solution to a sponsor's requirements that relies on a process which is fair and equitable to all stakeholders»,

where stakeholders here refer to the sponsor, the professional advisor, the jury, the technical committee, competitors, and the public. In such a process, people from various disciplines and professions are brought together to evaluate and render judgement on a series of architectural projects submitted by various competitors. There are many formats for architectural competitions: one or two phased, completely anonymous, partially anonymous, by invitation only or by submission of a dossier. A design brief typically contains the rules and guidelines as well as the criteria and requirements for the project. The members of the jury are made publically known when the competition 
is launched and carefully selected so that their backgrounds and perspectives are supportive of the task of selecting the winner. Finally, depending on the complexity of the brief or the amount of participants and whether a longer deliberation and judgement process is necessary, a jury can meet for more than one day (STrong 1996).

If the varied backgrounds of the jury members are meant to enrich the jury deliberation process, their lack of common world views may at times render the deliberation process coercive or unbalanced. What social, creative, argumentative or cognitive processes do the jury members adopt so that the process remains transparent, fair and constructive? One of the difficulties in judging competitions resides in the language and world view gaps that exist between the various stakeholders involved in competitions, and in particular between jury members and expert evaluators. This latter group represents a particular challenge within the theory of judgment and for the competition in general due to potentially different understandings of the difference between evaluation and judgement.

In addition, with the increasing international emphasis on quantitative standard methods for evaluating issues related to sustainability, there is concern that these may overcome other qualitative aspects of public space and buildings. This in turn, has implications on the way in which these projects are judged within the competition process.

Indeed, these standards have an impact on the nature of the competition for decision-makers, whether they are political or institutional, and have led in some cases, to competitions being used as the implicit privileged sole vehicle of communication of environmental policies instead of as a means of finding the best solution, in its entirety, to a given question. This phenomenon is particularly evident in the judgment process where these same environmental standards tend to overpower the more traditional criteria of quality evaluation, presenting themselves as «meta-criteria». Environmental performance thus seems to have become more important than quality of space or constructive choices.

One of the problems when tools like LEED become the defining criteria for sustainability is that the design as well as the judgment approach is often reduced to one of eco-efficiency (PRINCEN 2005; World Business Council for Sustainable Development - WBCSD 2000). This reduction leads to a deterministic approach to design and evaluation due to the underlying principle of prevention (Cucuzzella 2009; Cucuzzella \& De Coninck 2008; Polimeni et al. 2008). Such quantified results can provide the cognitive certainty that the public can relate to, even if it only reflects a perceived sense of certainty (Ellul 1964). Thus, it appears imperative for design and judgment in this context to shift from instrumental decision-making to critical exploration.

Several authors argue that reflective distance from deterministic-based evaluation methods is necesSary (HARPER \& STEIN 1992; JoNAS 1985) to prevent tools like LEED from becoming the driving force of our future due to their authoritative presence in all aspects of decision-making (Ellul 1964; Ellul 1987; HeIdegGer 1977). What tools like LEED provide is a means to democratize risks, in the sense that universal systems of indicators have been developed by national or international stakeholders with an interest in environmental building design. The problem with such democratized indicators is that they can become very abstract and sometimes far removed from the context in which they are to be applied (GuY \& Moore 2005a). These universal codes represent the values of their creators (on the most part an international set of stakeholders) and not the balanced value systems of a society within which they are adopted (GuY \& Moore 2005b). Such methods are simply an aggregated sum of a fragmented set of indicators - far from a representation of the complexity of the real world. Thus, attempts to conceptualize and judge an architectural project that seeks sustainability through a set of standard environmental indicators may have the effect that the complex reality of a design situation becomes fragmented. This could shift the focus of the qualitative dimensions of an architectural project to a set of quantitative indicators, possibly leading to a loss of coherence of the project.

Two examples of contemporary Canadian competitions have been chosen to illustrate the above discussed critical shift in the judgment process: the 2008 competition for the New Montreal Planetarium and the 2009 Saint-Laurent Library competition. Both competitions defined their sustainability criteria by the LEED norm. The relevant research data may be found in the Canadian Competitions Catalogue public database (see www.ccc.umontreal.ca).

The winning project, whose main visible components from the street level are its telescopic canon shaped theatres, blatantly symbolizing astronomical instruments, is otherwise immersed underground (see Figure 1). From the media perception, the most conventional of the projects submitted won, yet it met the strictest LEED standards (LEED Platinum), mainly from technical solutions. The multitude of press releases and documents connected to the project particularly emphasize the importance of the project for strengthening Montreal's position as a leader in sustainable development. Why this emphasis? Is the 


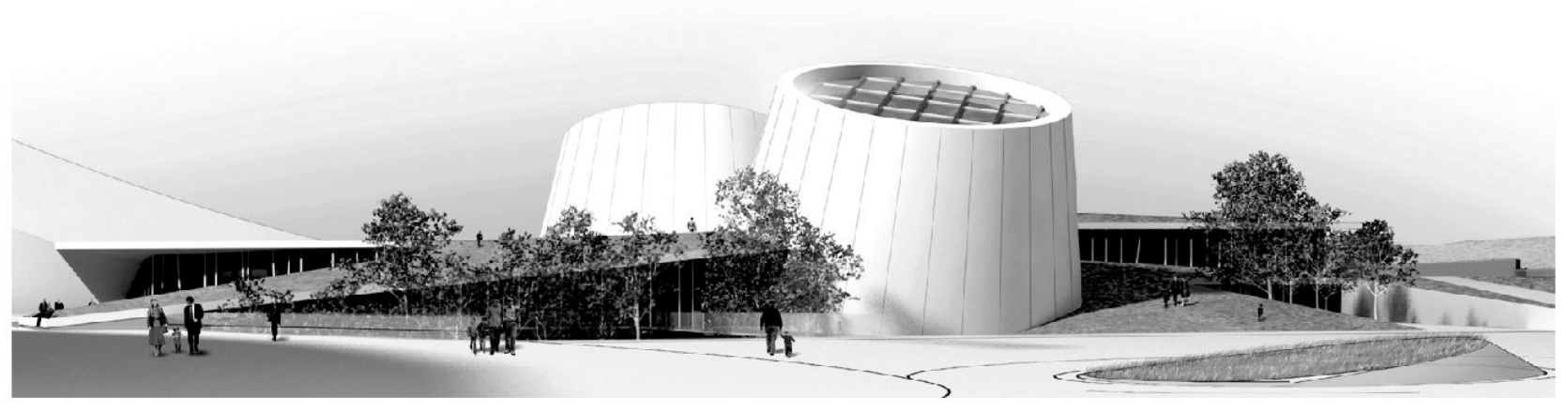

Fig. 1: View of the winning project for the Montreal Rio Tinto Planetarium competition (Canada, 2008). Team: Cardin+Ramirez/Aedifica/SNC Lavalin/Dupras-Ledoux/Fauteux et associés

The main visible components from the street level are the telescopic canon shaped theatres, symbolizing astronomical instruments - all other components are otherwise immersed underground.

Projet architectural du vainqueur du concours du Montréal Rio Tinto Planétarium (Canada, 2008). Equipe: Cardin+Ramirez/Aedifica/SNC Lavalin/Dupras-Ledoux/Fauteux et associés

Das Gewinner-Projekt des Wettbewerbs für das Montréal Rio Tinto Planetarium (Kanada, 2008). Team: Cardin+Ramirez/Aedifica/SNC Lavalin/Dupras-Ledoux/Fauteux et associés

purpose of such competitions to find the best solution for a public building or to communicate the status of a region's environmental policies? For some competition organizers, at least in the Canadian context, it now seems that reaching an ultimate LEED norm is more important than other architectural qualities. Although LEED remains a highly significant analytical tool helping designers to address a series of ecological concerns, its dominant position in architectural competitions may lead to other important architectural concerns not being appropriately addressed and may obscure the cultural and social motivations that architectural projects as unique as this may provide.

The Saint-Laurent Library competition, launched in 2009 for the borough of Saint-Laurent in Montreal is another example of a competition which strongly emphasized environmental evaluation. The certification requirement for this competition was LEED Gold. The winning team addressed the objective of sustainability through a series of technical solutions based solely on LEED categorizations, without providing arguments for the wider impact of the project at cultural or social levels. This is contradictory to current views of sustainability which also call for the consideration of aesthetic and symbolic aspects of architectural projects. As GUY and FARMER state (2000: 79), «our ethical responsibility is in creating a new architectural iconography that has transformative value in altering our consciousness of Nature».

In the light of this statement, one can question the appropriateness of the monumentality of the winning project: its immense front door to the forest hides much of the forest from the street, its imposing structure implies an overpowering of nature and there is little attempt to incorporate the essence of the natural surroundings in the architecture (see Figure 2). According to GuY and FARMER (2000: 80),

«the role of green buildings is [...] not simply to reduce the energy consumption or the ecological footprint of buildings, but to inspire and convey an increasing identification with Nature and the non-human world».

As the emphasis on LEED in this competition was so strong, most of the other finalist projects were also trapped into the «ratings game»; it appeared more important to accumulate LEED points than to explore innovative ways for addressing the given architectural and urban challenges. The result was that the only project that provided a solution addressing a «new architectural iconography» through its aesthetic details inspired by the nature surrounding the site was also considered by the jury in their report as the riskiest in terms of attaining the required LEED credits (see Figure 3).

The primary analysis of these two competitions already indicates that there is an emerging difficulty in the use of standard environmental evaluation methods for competitions, which has to date been neglected. Their dominance could lead to less attention being paid to cultural or social sustainability. This may therefore lead to the shifting of repercussions from one 


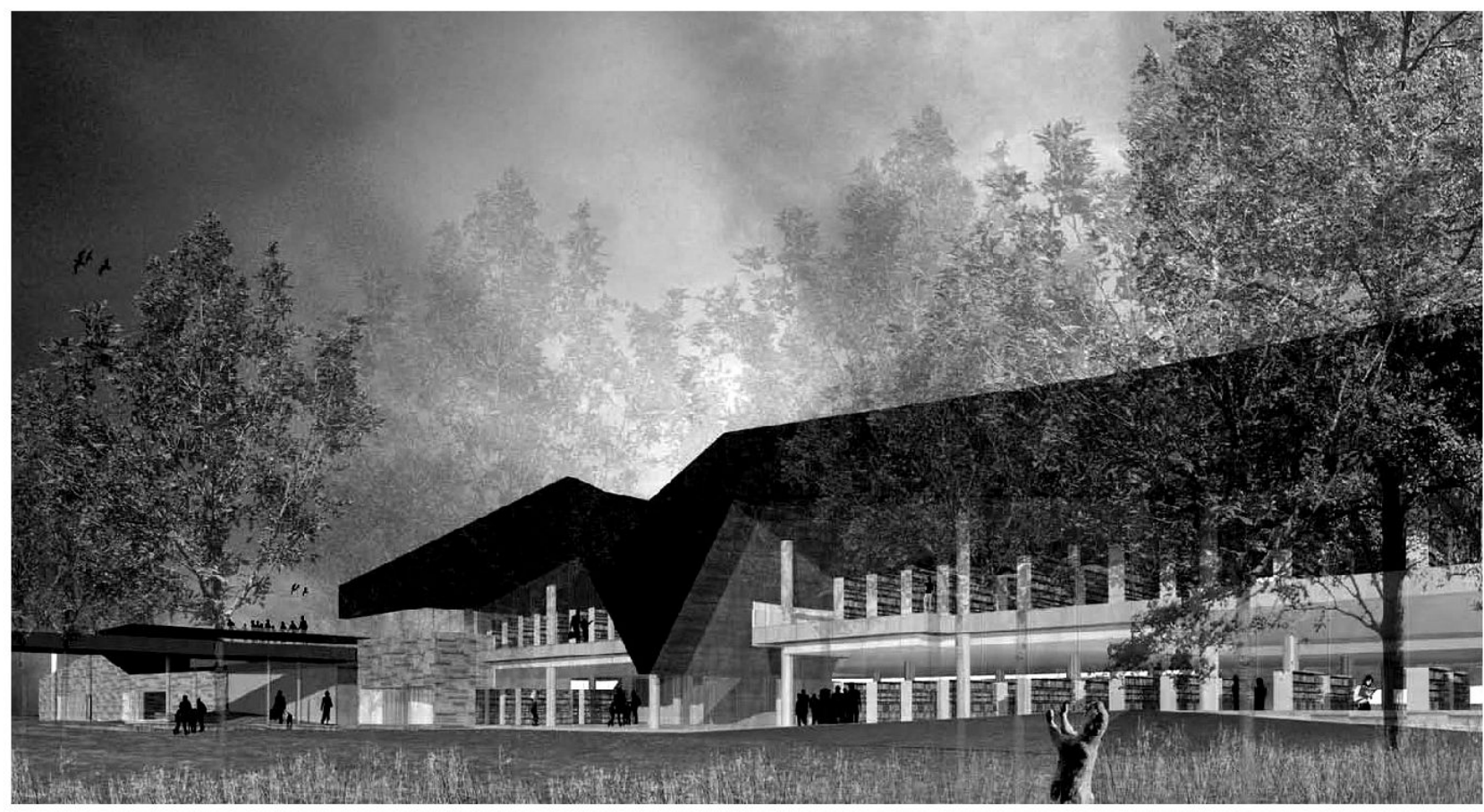

Fig. 2: View of the winning project for the Saint-Laurent library competition (Canada, 2009). Team: Cardinal Hardy/Labonté Marcil/Éric Pelletier Architectes en consortium/Leroux Beaudoin Hurens et associés inc./SDK et associés inc.

A contradiction exists between its imposing structure and the way in which it seems to overpower nature instead of trying to express the essence of its natural surroundings.

Projet architectural du vainqueur du concours de la bibliothèque de Saint-Laurent (Canada, 2009). Equipe: Cardinal Hardy/Labonté Marcil/Éric Pelletier Architectes en consortium/Leroux Beaudoin Hurens et associés inc./ SDK et associés inc.

Das Gewinner-Projekt des Wettbewerbs für die Saint-Laurent Bibliothek (Kanada, 2009). Team: Cardinal Hardy/ Labonté Marcil/Éric Pelletier Architectes en consortium/Leroux Beaudoin Hurens et associés inc./SDK et associés inc.

domain of sustainability to another. In other words, the result may be that the impacts of an architectural project are shifted from, for example, the environmental pillar to the cultural pillar of sustainability. In this sense, the global sustainability crisis will not have been appropriately addressed. As the use of environmental standards is no longer negotiable for many public architectural and urban projects, a critical awareness of their impact on the qualitative practices of these projects is necessary. In particular, some of the problems emerging in the judgment process may be traced to the fact that there is often confusion about the difference between evaluation and judgment.

\section{Distinguishing between the concepts of evaluation and judgment}

According to the American pragmatist JAMES DEWEY (1980), discord, conflict, disagreement, or dissonance induce reflection of a situation, experience or object of observation. One cannot ignore the reflection necessary to comprehend this discord or conflict, and by doing so, can resist from oversimplifying the problem. He defines judgment as criticism and states further:

«Judgment has to evoke a clearer consciousness of constituent parts and to discover how consistently these parts are related to form a whole. Theory gives the name of analysis and synthesis to the execution of these functions» (p. 310).

DEwEY, however, prefers to refer to these functions as discrimination and unification, and claims that the unifying phase (synthesis) is in fact the creative response of the individual who judges and that without a unifying view, criticism (and therefore judgment or emergence) ends in the enumeration of details. The author of «How We Think» (1933) claims that there are three main characteristics of judgment: (1) a controversy, consisting of opposite claims; (2) a process for defining and elaborating claims and of sifting through facts; 


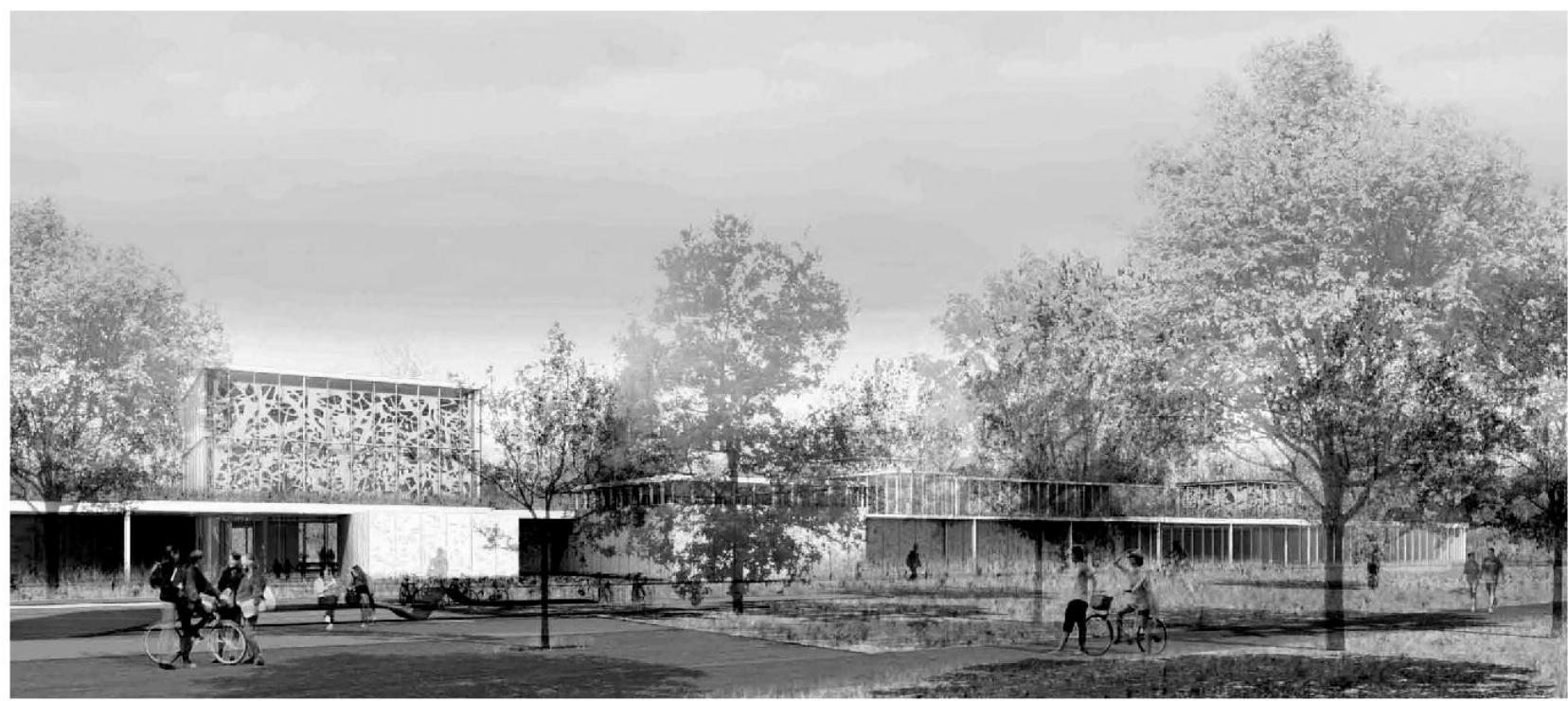

Fig. 3: View of a finalist project for the Saint-Laurent library competition (Canada, 2009). Team: Chevalier Morales Architectes/Les Architectes FABG/Tecsult-AECOM inc.

The only project that provided a solution addressing a «new architectural iconography» through its aesthetic details inspired by the nature surrounding the site was also considered by the jury in their report as the riskiest in terms of attaining the required LEED credits.

Projet finaliste du concours de la bibliothèque de Saint-Laurent (Canada, 2009). Equipe: Chevalier Morales Architectes/Les Architectes FABG/Tecsult-AECOM inc.

Ein Finalisten-Projekt des Wettbewerbs für die Saint-Laurent Bibliothek (Kanada, 2009). Team:Chevalier Morales Architectes/Les Architectes FABG/Tecsult-AECOM inc.

and (3) a final decision, therefore arriving at closure - a consensus. A judgment therefore arises only when there are different meanings, rival interpretations, points of contention regarding some matter at stake, in short, when there is doubt and controversy. Evaluation, on the other hand, is the specific analysis of constituent parts of a whole, an inevitable activity in the criticism of a whole.

The judgment of architectural projects therefore can hardly be evaded through the «efficient» use of quantitative tools which rely on abstract models of a world. In fact, SсHÖN (1983) stated that the complexity, uncertainty, uniqueness, and value-conflict so prevalent in real world situations, such as in architectural situations, do not fit the model of «Technical Rationality», since in this perspective they are reduced to problemsolving exercises. This problem-solving approach is the space in which many evaluation methods still exist, a puzzling anomaly in the context of conceptualizing and judging architectural projects. If this technical knowledge is placed within the broader context of reflective inquiry, then the link between the uncertainty and uniqueness prevalent in practice and the more quantitative approaches to evaluation of tech- nical dimensions of any project are made possible. This critical perspective is what SснӧN (1983) refers to as reflection-in-action, a necessary activity during the conceptualization or judgment of a project whose constituent parts are evaluated using methods that lie within the quantitative, measurable, provable doctrine.

\section{Complexity of the judgment process for the architectural competition}

Considering the above argumentation, the distinction between evaluation and judgment is especially relevant within the context of the architectural competition. Expert evaluators, generally external to the jury process, provide quantified information to the jury regarding a series of technical (e.g. structural, financial, environmental) evaluations. These evaluations are imperatively done before the jury deliberation and must be taken into consideration along with all other relevant aspects by each juror. But, they remain expert data and do not have the status of judgment, since judgment is comprised of not only evidential data, but also of a set of principles as well as tacit knowledge. Thus, the main distinguishing characteristic between evalua- 
tion and judgment for the competition process is that evaluation is a process in which each of the elements within it are systematically assessed in the exact same manner according to the model of technical rationality. This is very different from the deliberation process of judgment, which is predominantly a recursive process, meaning that each consideration and reflection has a consequence on the considerations that follow reflection-in-action, as defined by ScHöN (1983). In the judgment process, there is therefore a constant oscillation between these two activities.

In the next section, a new theoretical model of judgement is presented as «judgment by design». The advantages of the model are seen in its potential to support a more accurate understanding of common dimensions of judgment in the domain of architecture, landscape and urbanism, and therefore a better contextualization of standards in this complex qualitative process, now seen as a reflective process.

\section{5 «Judgment by design» as a critical model}

Rather than viewing judgment as a separate process from design, jurors may be considered the re-designers of the potential winning project. From this point of view, the judgment process requires jurors to converge on a project, to the point where they can appropriate it and make it theirs in a common decision. Since the winner is the «product» of the judgment process, it follows that the product is the «project of the jury», as if the jury had designed it (CHUPIN 2011b). It is important to highlight that this paradigm shift does not prescribe a new way of judging, but is intended to convey a better description of an existing reality.

In this line of reasoning, if a judgment process is analogous to a design process, on what theoretical model of the design process can we rely on to conceptualize judgment? In other words, can we agree on a design model that could handle the complexity of the basic operations of judgment by a jury? The history of the self named movement of «design methods and methodologies» from the 1960 s to the 1990 s has been dealt with sufficiently by various historians: BROADBENT (1988), Cross (1984), BuchanAN and Margolin (1995), Rowe (1987), Boudon (1993), CHupin (2010). This history has already shown not only the difficulties encountered by the scholars who have attempted this task, but also the contradictions to which they have been exposed when trying to understand a complex system such as design thinking. In the limits of this article three classical models are presented: (1) design as variety restriction; (2) acceptable solutions versus feasible solutions; and (3) synthesis of spiral patterns. The description of the models starts with the simplest of the three.

\subsection{Design as variety restriction}

In the 1960's a number of researchers considered design to be a process of simplification. For example, GoRdon BEst, a young researcher at the Symposium of Portsmouth in 1967, presented an outline of what he called the «design variety restriction» (BEST 1969). In this model (see Figure 4), the initial situation is understood as an ill-formed set of requirements. From an initial situation, the designer is supposed to move towards a so-called design solution by going through a set of intertwined interpretive operations and information structuring. Following this simplistic model, which has been largely criticised since, the question that arises is: Is there any relevance for describing the jury experience today through this simplistic model? This model describing a process going from unstructured to structured information would imply that the jury receives an unstructured stack of proposals and indeed, this is essentially what the jury perceives when faced with an impressive number of panels and projects. In some competitions a jury can review more than one hundred proposals presented in the form of 2-3 panels. Since the task of the jury is to identify the most appropriate solution through a series of interpretive phases, then according to this model, the closer the jurors get to the final decision, the simpler the decision becomes since the alternatives are increasingly reduced. What BEST calls a «design variety restriction». Unfortunately, our empirical observations of the jury deliberation processes showed that it is in fact the opposite, meaning that the conflicts of interpretation increase as the number of projects are reduced. Are these divergences in judgment (1) conflicts of interpretation, (2) types of misunderstandings, (3) problems of translation, or something else? This model, which is not only simplistic regarding the description of the design process, remains too generic to describe the judgment process.

Today, most researchers are aware of the difficulties encountered by those who sought to represent the design process in the past. Regrettably, it often takes a long time before developments at the theoretical level have an impact on practice. If the design process as a form of problem-solving has long been questioned in theoretical circles, it is still however an accepted paradigm in current practice and this disjunction of interpretation complicates the observation of the phenomena. This is a common paradox of reflective practices (RowE 1987; ScHöN 1983).

Many studies have shown that there can be no simple solution to a problem, first and foremost because it is not always clear whether the situation being dealt with is a problem. The notion of «wicked-problem» first proposed by Horst RitTel (Buchanan 1992) is a way of describing the paradoxes of the design process. If 


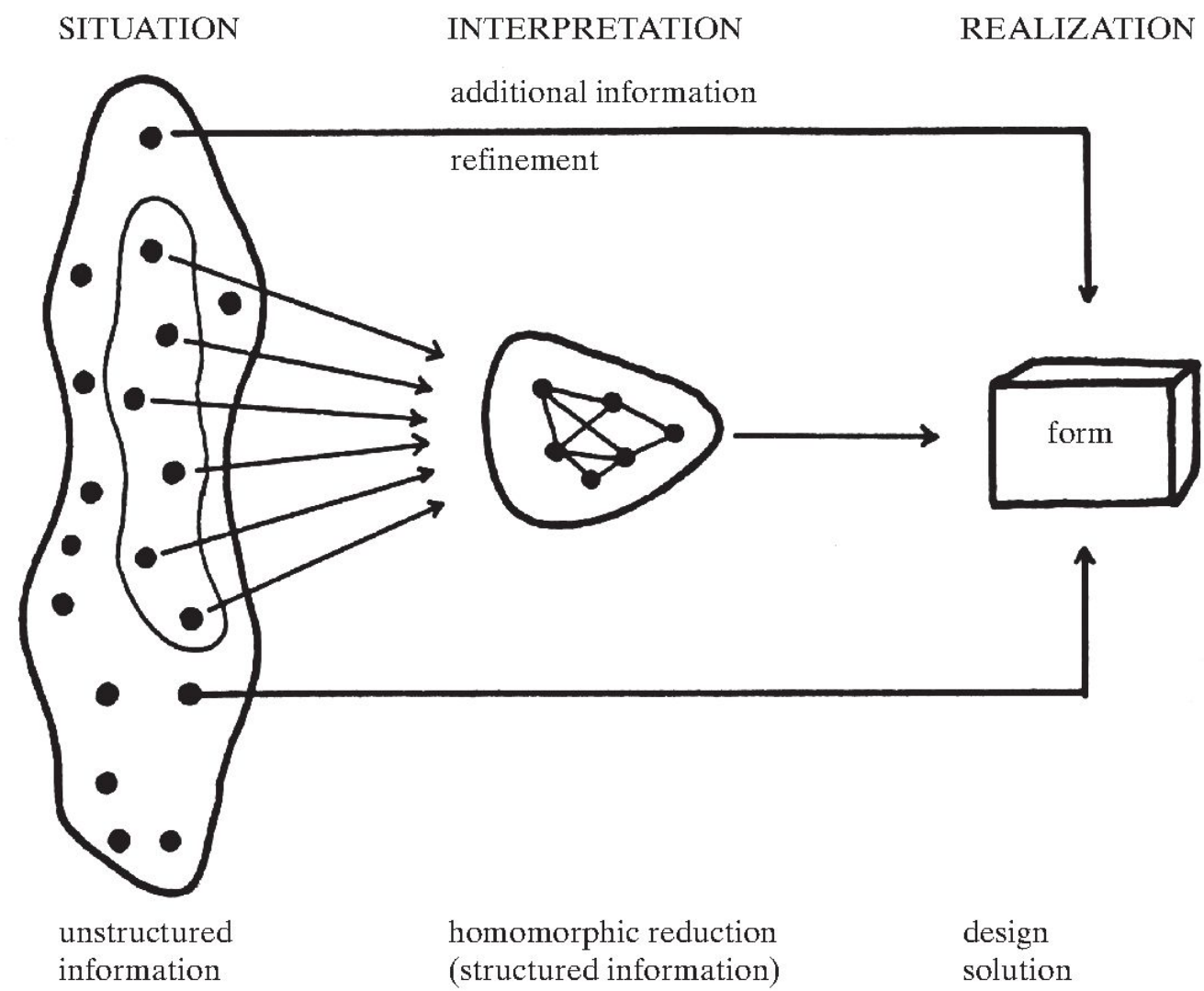

Fig. 4: Diagram of the design process by G. BEST (1969)

Notice the passage from the initial situation (non-form) to the solution (square) of the problem through a generic process of «variety reduction».

Diagramme du processus de conception selon G. BEST (1969)

Diagramm des Design-Prozesses von G. BEST (1969)

Source: BEST 1969, in: BROADBENT \& WARD 1969: 157

in a well-structured problem, all parameters are easily identifiable; in an ill-structured problem or wickedproblem, one or more constituents are missing. RITTEL and Webier (1973) identified at least ten characteristics of what they called the «wicked problems of planning»: for example, the lack of a definitive formulation, no stopping rule, solutions that are not true-or-false but good-or-bad, no ultimate test for a solution, a lack of opportunity to learn by trial-and-error and no enumerable set of potential solutions. In addition, the preconceptions of judges, as well as their prejudices, affect the judging process as much as the preconceptions of a designer when approaching their project. Here, again, numerous well-known research projects have shown that not only do preconceptions filter the view of the designer, but they have a determining, in fact, a necessary role, in the launch of the process, the latter function termed by DARKE (1979) as «primary generators». Following this, when transposed to the jury process, these observations imply that jurors cannot be devoid of preconceptions. So, how does a collectivity of jurors deal with the variety of preconceptions?

\subsection{Acceptable solutions versus feasible solutions}

The question of design problems can be dealt with from the opposite side, i.e. design solutions instead of design problems. What is a design solution? And how does it relate to the result of a judgment process? BRUCE ARCHER, another historical figure of «design methods» presented a neo-Cartesian model of the complexity of a solution (ARCHER 1969). Following his diagram (see Figure 5), the area of the solution would be at the intersection of the domain of acceptability and the domain of feasibility. A competition jury, who must constantly oscillate between that which is acceptable and that which is deemed feasible for the given situation is often familiar with this ambivalence. However, these choices are linked to the knowledge of each juror, and are triggered by their preconceptions, as previously mentioned. In other words, if applied to 


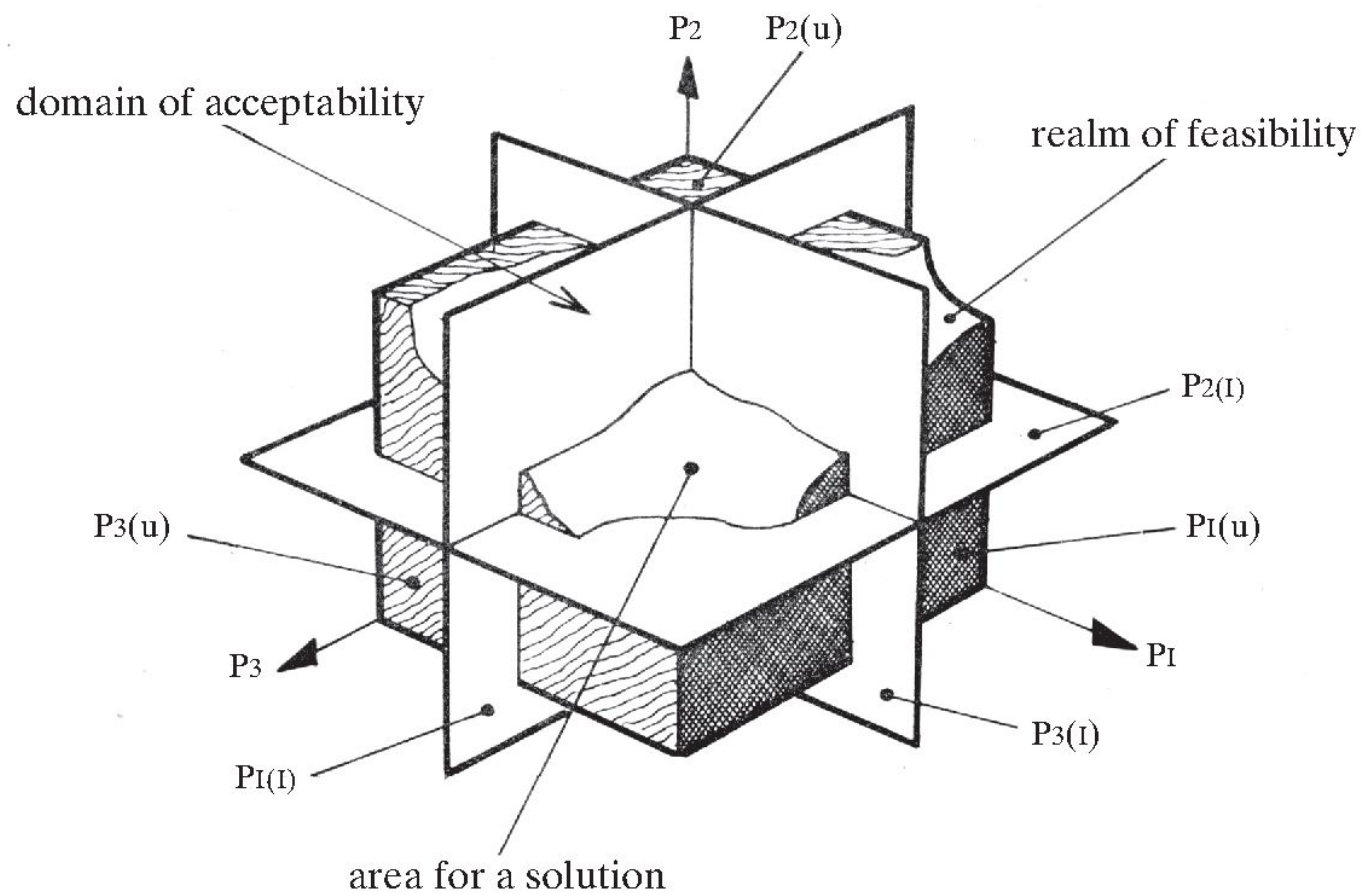

Fig. 5: The solution space by L.B. Archer (1969)

Cartesian model distinguishing the realm of feasibility, the domain of acceptability, and the solution space: «The interdependence of the states of the properties constitutes an n-dimensional hypersurface on the realm of feasibility. The product of the erection of limiting states of the properties is an $\mathbf{n}$-dimensional space or domain of acceptability. The superimposition of the domain of acceptability on the realm of feasibility marks out the arena within which a solution is to be selected».

L'espace de solutions selon L.B. ARCHER (1969)

Der Lösungs-Raum von L.B. ARCHER (1969)

Source: ArCHER 1969, in: BRoADBEnT \& WARD 1969: 83

judgment, this understanding of the design process would require that jurors recognize the limits of what is acceptable and what can be judged feasible. Again, empirical observation shows that a jury is rarely composed with such precautions in mind (CHUPIN 2011a; Cucuzzella 2011).

\subsection{Synthetic spiral model}

In spite of the difficulties encountered by researchers dealing with issues of design thinking in the 1960's and 1970 's, there has been some significant progress in 1980 's. John ZeISEL schematised a series of previous models into a general «spiral model» in «Inquiry by Design» in 1981 (see Figure 6). Initially embedding it within a behaviourist theoretical framework, he republished it again in 2006 using a lexicon inspired by the field of neurosciences (ZEISEL 2006). Given that a demonstration for validating this model for the representation of design is no longer necessary, the focus here is on what it can contribute towards the theory of judgment. The model is based on a series of iterations, starting from an initial image, where it revolves around a domain of acceptable responses. The cyclic nature of design is also reflected in the judgment process, with each juror reviewing the visual presentations over many cycles to ensure sufficient understanding of the proposals involved. However, the cycle of comparison does not suffice to converge to a winning project. Jurors should be able to make «conceptual leaps» using predominantly analogical thinking (CHUPIN 2010). At the end of the process, jurors take a decision after a variable number of conceptualization cycles. Following this model, it is easier to describe the relationship between a juror and a project as dependant on cycles of imagination and formalization through which the jury progressively «re-presents» and one can even say, «re-designs» the ultimate proposal. From this description, it is clear that the model is not linear because the jury's perception of the process is anything but linear and incremental. There is a point of departure and a point of arrival, but there are also moments during which the jury seems to regress, go back and reflect. They may seem to go backwards, but, in reality, they have nevertheless made progress in their compre- 


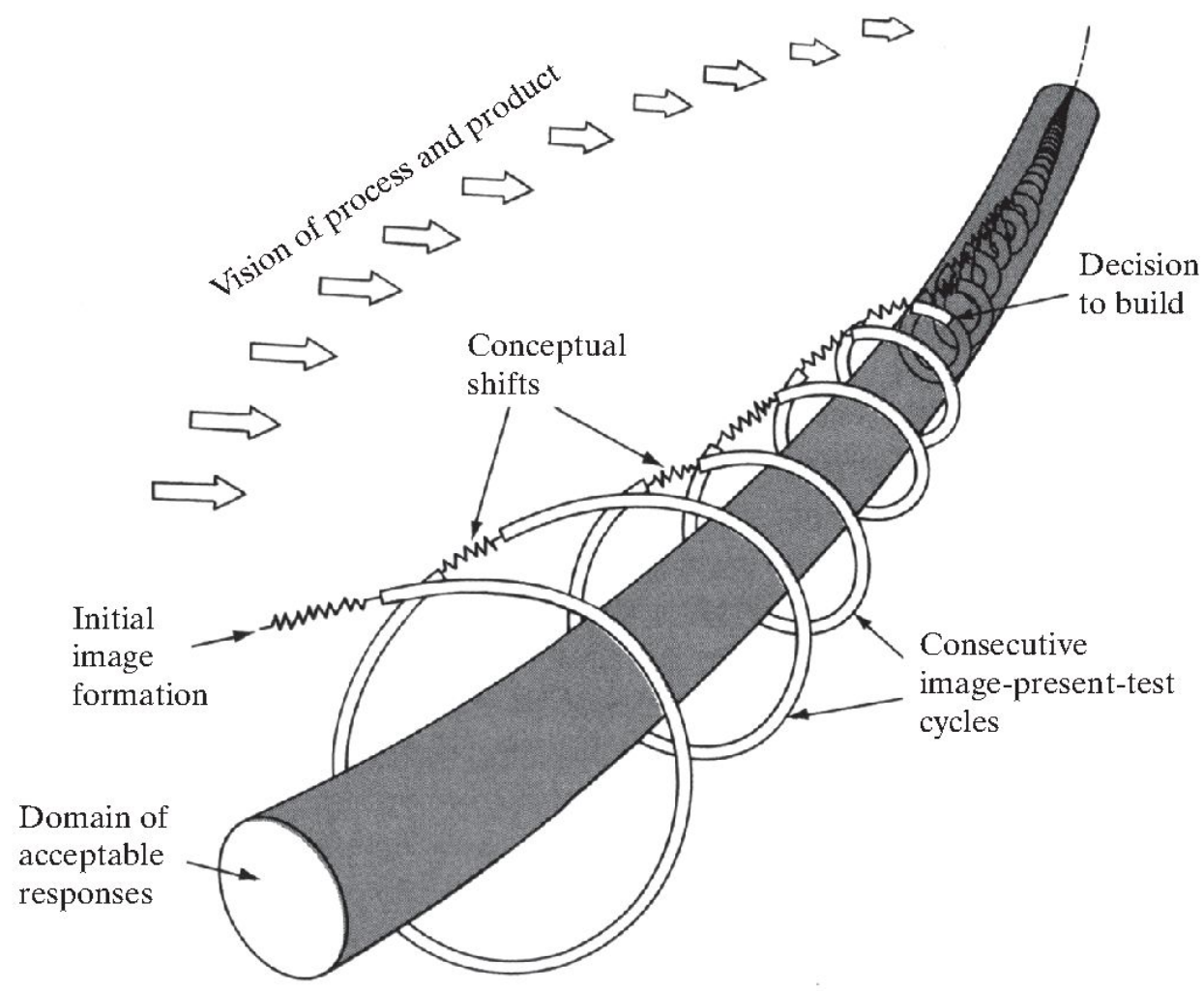

Fig. 6: Development spiral of design by J. ZeISEL (1981).

In the republished version of 2006,25 years later, the author reformulates the legends adopting a lexicon inspired by research in neurosciences and artificial intelligence but the diagram is strictly identical.

La spirale de la conception selon J. ZEISEL (1981)

Die Design-Entwicklungs-Spirale von J. ZeISEL (1981)

Source: ZeISEL 1981, 2006: 30

hension of the situation since the spiral is not flat but three-dimensional, like helicoids, all attributes of a recursive process.

However, a crucial concept for understanding design and critical judgment is that of the notion of reflectivity, as put forward by DONALD A. SсHÖN in various seminal publications (1984, 1983). SснӧN particularly insists on the correlation between reflectivity and the power to conceptualize. He showed that the best designers constantly enrich their projects, challenge their preconceptions, are able to take a critical distance from their project, and are able to distance themselves from their own approach: all attributes of «reflective practice». Within this set of attributes, all equally important for critical judgment, that the use of environmental standards can be contextualized within the design thinking process.

Within ZeISEL's synthetic spiral model, the notion of reflectivity is represented as a row of arrows follow- ing the progress of the project and which the author labels as the «vision of process and product». What are the correspondences for judgment? First, we can say that jurors do not all have the same reflective ability, which also comes with experience, habit, critical thinking and especially from the inherent culture of the domain. This implies that jurors should not be fixated on their own idea of the winning project, and at the same time be able to recognize that the selected scheme will in some way be «their own» project. They can look at the same project from divergent vantage points but they should be able to step back and reflect, and if necessary, acknowledge arguments that challenge their own, even if this would imply the need to reconsider a project that may have been dismissed too early. In other words, jurors should be open to enriching their «project», challenging their preconceptions, and making use of critical distance, very much like any designer should.

This demonstration rests at once on empirical obser- 
vations of jury deliberations and a critical history of the domain of design. Future research will be necessary to delineate a model of judgment that may indeed be more representative of the complexity of architectural judgment (CoLlins 1971). However, we can already conclude that following the «judging by design» model, a jury has a similar function as the head of an architecture or urban design firm. Rather than being practically involved, their function is to give feedback, resolve, approve, evaluate, assess and redirect at critical points in the project. Most of these interventions are typical reflective operations. Given that the jury is representative of the complexity of the public in a democratic system of decision making, this collective reflectivity is indeed at the core of the judgment process. This is why rejecting the competition process based on its lack of representativity of the public good can only be a frustration following a badly judged competition. In the same way, imposing environmental norms as the main criteria for a judgment process reduces the complexity of architectural quality, just as it reduces the complexity of sustainability to one of eco-efficiency.

\section{References}

ADAmczyK, G. (2004): Concours et qualité architecturale. - ARQ/Architecture-Québec 126: 4-24.

Archer, L.B. (1969): The structure of the design process. - In: Broadbent, G. \& A. WARD (eds): Design methods in architecture. - London: AA papers: 83.

BEST, G. (1969): Method and intention in architectural design. - In: BroAdBent, G. \& A. WARD (eds): Design methods in architecture. - London: AA papers: 157.

Boudon, P. (1993): Conceptions de la conception. - In: Cahiers de la recherche architecturale 34: 71-83.

BroadBent, G. (1988): Design in architecture (Architecture and the Human Sciences). - London: David Fulton.

BroAdBent, G. \& A. WARD (eds) (1969): Design methods in architecture. - London: Lund Humphries.

BuCHANAN, R. (1992): Wicked problems in design thinking. - In: Design Issues VIII, 2: 5-21.

Buchanan, R. \& V. Margolin (eds) (1995): Discovering design - Explorations in design studies. - Chicago: The University of Chicago Press.

Chupin, J.-P. (2010): Analogie et théorie en architecture (De la vie, de la ville et de la conception, même). - Genève: Infolio.

CHuPIN, J.-P. (2011a): Quand juger c'est «concevoir un projet». - In: ARQ/Architecture-Québec 154: 48-51.

Chupin, J.-P. (2011b): Judgement by design: Towards a model for studying and improving the competition process in architecture and urban design. - In: The Scandinavian Journal of Management (forthcoming). Collins, P. (1971): Architectural judgement. - Montreal: McGill-Queen's University Press.
Cross, N. (ed.) (1984): Developments in design methodology. - Chichester: Wiley.

Cucuzzella, C. (2009): An evaluation and innovation framework for responsible design based on prudence. - In: Malins, J. (ed.): Proceedings of the 8th European Academy of Design Conference, April 1-3, The Robert Gordon University, Aberdeen, Scotland: 109-114.

Cucuzzella, C. (2011): Les limites de LEED, ARQ. In: ARQ/Architecture-Québec 154: 22-25.

Cucuzzella, C. \& P. DE Coninck (2008): In pursuit of sustainable consumption: The limits of adopting a strategy of efficiency. - Proceedings of the 8th International Conference on Ecobalance, December 10-12, Tokyo, Japan.

DARKE, J. (1979): The primary generator and the design process. - In: Environmental Design Research Association 9: 325-337.

Dewey, J. (1933): How we think. - Boston, D.C.: Heath and Company.

Dewey, J. (1980): Art as experience. - New York: Perigee Books.

Ellul, J. (1964): The technological society. - New York: Vintage Books.

Ellul, J. (1987): Le bluff technologique. - Paris: Hachette.

GuY, S. \& G. FARMER (2000): Contested constructions: the competing logics of green buildings and ethics. In: Fox, W. (ed.): Ethics and the built environment. London: Routledge.

GuY, S. \& S.A. Moore (2005a): Introduction: The paradoxes of sustainable architecture. - In: GuY, S. \& S.A. Moore (eds): Sustainable architectures: cultures and natures in Europe and North America. - New York and London: Spon Press.

GuY, S. \& S.A. Moore (eds) (2005b): Sustainable architectures: cultures and natures in Europe and North America. - New York and London: Spon Press.

HARPER, T.L. \& S.M. STEIN (1992): The centrality of normative ethical theory to contemporary planning theory. - In: Journal of Planning Education and Research 11, 2: 105-116.

Heidegger, M. (1977): The question concerning technology and other essays. - New York: Harper \& Row. JonAs, H. (1985): The imperative of responsibility: in search of an ethics for the technological age. - Chicago: University of Chicago Press.

Moore, S.A. \& N. Engstrom (2005): The social construction of «Green Building» Codes. - In: GuY, S. \& S.A. Moore (eds): Sustainable architectures: cultures and natures in Europe and North America. - New York and London: Spon Press.

Polimeni, J.M., Mayumi, K., Giampietro, M. \& B. AlcotT (2008): The Jevons paradox and the myth of resource efficiency improvements. - London: Earthscan Publications.

Princen, T. (2005): The logic of sufficiency. - Cambridge: MIT Press. 
Rowe, P.G. (1987): Design thinking. - Cambridge, Massachusetts: The MIT Press.

ScHön, D.A. (1983): The reflective practitioner: How professionals think in action. - New York: Basic Books. ScHön, D.A. (1984): The architectural studio as an examplar for reflection-in-action. - Journal of Architectural Education 38, 1: 2-9.

STRONG, J. (1996): Winning by design: architectural competitions. - Boston: Butterworth-Heinemann.

World Business Council for Sustainable DevelopMENT - WBCSD (2000): Eco-efficiency: creating more value with less impact. - Geneva:WBCSD.

ZeIseL, J. (1981): Inquiry by design - Tools for environmental behavior research. - Monterey, California: Books/Cole.

ZeISEL, J. (2006): Inquiry by design. Environment, behavior, neuroscience in architecture, interiors, landscape, and planning. - Revised edition, New York: W.W. Norton \& Company.

\section{Summary: Environmental standards and judgment processes in competitions for public buildings}

This article highlights the often underestimated impact of environmental standards on the judgment process with particular reference to contemporary Canadian competitions for public buildings. It argues that recent attention given to environmental standards could lead to a potential crisis in the competition process. After establishing a clear distinction between evaluation and judgment, the article offers to reassess current practices through a theoretical model which shifts from «judgment on design» to «judgment by design».

Keywords: environmental design, environmental standards, competitions for public buildings, evaluation, qualitative judgment, design thinking, geographies of architecture, architectural and urban forms

\section{Résumé: Normes environnementales et processus de jugement dans les concours d'édifices publics}

En dépit de leur importance dans la qualité des constructions et des espaces publics, les procédures de jugement en situation de concours d'architecture, de paysage et d'urbanisme ont été très peu étudiées et encore moins théorisées. Dans ce vide théorique, l'introduction récente de deux facteurs est venue compliquer les opérations relatives au jugement: d'une part la demande croissante pour une plus grande diversification des points de vue dans la composition des jurys réduisant, comme c'est actuellement le cas dans le contexte canadien, le rôle des architectes et, d'autre part, l'introduction systématique des normes environnementales (par exemple LEED). Cet article propose de considérer un nouveau modèle du jugement, appelé «concevoir en jugeant» qui permet non seulement de modéliser les traits caractéristiques du jugement dans les domaines de l'architecture, du paysage et de l'urbanisme, mais également de situer ces normes à leur juste place dans le processus.

Mots-clés: conception des environnements humains, normes environnementales, concours d'édifices publics, évaluation, jugement qualitatif, géographies de l'architecture, formes architecturales et urbaines

\section{Zusammenfassung: Umweltstandards und Entschei- dungsprozesse bei Wettbewerben für öffentliche Gebäude}

Entgegen ihrer prägnanten Rolle hinsichtlich der Qualität öffentlicher Bauten wurde der Jurierungsprozess in Wettbewerbsverfahren in der Stadt- und Landschaftsplanung sowie in der Architektur bislang ungenügend theoretisch durchleuchtet. Zwei jüngst hinzukommende Faktoren komplizieren die jurybasierte Entscheidungsfindung im genannten theoretischen Vakuum: Einerseits wächst die Forderung nach einer Diversifizierung der Jury-Mitglieder. Die geforderte Heterogenität wird (im kanadischen Kontext) als Massnahme zur Sicherstellung der Multiplizität von Standpunkten verstanden. Andererseits verändert der zunehmende Gebrauch von Umwelt-Standards (z.B. LEED) die Entscheidungsfindung. Im Artikel wird ein Modell präsentiert, welches als «Judgement by Design» bezeichnet wird. Dieses verdeutlicht einerseits die gemeinsamen Charakteristiken von Wettbewerben in den Bereichen Architektur, Stadt- und Landschaftsplanung, erlaubt aber vor allem, die entsprechenden Normen adäquat im Prozess zu situieren.

Schlüsselwörter: Umweltgestaltung, Umweltstandards, Wettbewerb für öffentliche Bauten, Evaluation, qualitative Beurteilung, Design Thinking, Geographies of Architecture, Architektur und Städtebau

Prof. Dr. Jean-Pierre Chupin, Director of L.E.A.P., Université de Montréal, CP 6128 succ. Centre-Ville, Montréal, Québec, H3C 3J7, Canada.

e-mail: jean-pierre.chupin@umontreal.ca

Carmela Cucuzzella, PhD Candidate, Coordinator of research assistants at L.E.A.P., Université de Montréal, CP 6128 succ. Centre-Ville, Montréal, Québec, H3C 3J7, Canada.

e-mail: carmela.cucuzzella@umontreal.ca

\section{Manuskripteingang/received/manuscrit reçu le 5.11.2010 \\ Annahme zum Druck/accepted for publication/accepté pour publication: 9.3.2011}

